\title{
PENERAPAN METODE DRILL DALAM PEMBELAJARAN BAHASA ARAB UNTUK MENINGKATKAN HASIL BELAJAR
}

\author{
Hafidh Nur Fauzi \\ Program Studi Magister Pendidikan Agama Islam \\ Universitas Ahmad Dahlan Yogyakarta \\ E-mail: Hafidhnurfauzi90@gmail.com \\ Muhammad Arif Darmawan \\ Program Studi Magister Pendidikan Agama Islam \\ Universitas Ahmad Dahlan Yogyakarta \\ Arifdarmawandaarulkhoir74769@gmail.com
}

\begin{abstract}
Abstrak
Penelitian ini di latar belakangi berdasarkan observasi yang dilakukan di SD Muhammadiyah Pendowoharjo Sewon Bantul. Kualitas hasil belajar bahasa arab masih di bawah KKM, penelitian bertujuan untuk mengetahu apakah ada pengaruh penerapan metode drill terhadap hasil belajar siswa/siswi kelas $\mathrm{V}$ di SD Muhammadiyah Pendowoharjo. Penelitian ini adalah Penelitian Tindakan Kelas (PTK) sebagai objek penelitian adalah siswa kelas V SD Muhammadiyah Pendowoharjo prosedur penelitian berbentuk siklus mengacu pada empat komponen meliputi perencanaan (planning), tindakan (acting), pengamatan (observing), dan refleksi (reflecting) dan teknik pengumpulan data menggunakan observasi dan tes. Hasil penelitian menunjukkan penggunakan metode drill di pelajaran bahasa arab dapat meningkatkan hasil belajar siswa berdasarkan data rekapitulasi hasil tes siswa dari siklus 1 dan siklus 2 presentase KKM siswa meningkat mencapai $75 \%$ yang sebelumnya hanya $50 \%$ dan dari $75 \%$ hanya 3 orang siswa yang belum mencapai nilai KKM yaitu 71 dari 12 siswa.
\end{abstract}

Kata kunci: Metode Drill, pembelajaran bahasa arab, hasil belajar

\section{Abstract}

This research is based on observations made at the Muhammadiyah Elementary School Pendowoharjo Sewon Bantul. The quality of Arabic learning outcomes is still below KKM, the research aims to find out whether there is an influence of the 
Hafidh Nur Fauzi, Muhammad Arif Darmawan : Penerapan Metode Drill dalam Pembelajaran Bahasa Arab untuk Meningkatkan Hasil Belajar

application of the drill method to the learning outcomes of students in grade $V$ in Muhammadiyah Pendowoharjo Elementary School. This research is Classroom Action Research (CAR) as the object of research is the fifth grade students of $S D$ Muhammadiyah Pendowoharjo cycle research procedures referring to four components including planning, acting, observing, and reflecting and engineering Data collection uses observation and tests. The results showed the use of the drill method in Arabic language lessons could improve student learning outcomes based on recapitulation data of student test results from cycle 1 and cycle 2, the percentage of KKM students increased to $75 \%$, which was previously only $50 \%$ and from $75 \%$ only 3 students who had not yet reached KKM scores are 71 out of 12 students.

\section{Keywords: Drill Method, Arabic learning, learning outcomes.}

\section{A. Pendahuluan}

Penelitian ini dilatarbelakangi oleh adanya potensi dan masalah, potensi yang di maksud adalah banyaknya buku-buku yang membahas tentang metode dan strategi pembelajaran dengan mudah kita temukan di perpustakaan dan di toko-toko buku yang dapat di implementasikan dalam dunia pendidikan. Namun yang menjadi masalah adalah belum banyaknya metodemetode yang membahas tentang metode dalam pembelajaran bahasa arab yang dapat di gunakan dalam pembelajaran di sekolah atau di madrasah oleh karena itu di perlukan penerapan metode yang cocok dengan pembelajaran bahasa arab.

Pada umumnya di madrasah dan sekolah-sekolah di Indonesia yang memiliki mata pelajaran Bahasa Arab, mereka para siswa/siswi sangat kesulitan dalam memahami dan mencerna pelajaran tersebut, di karenakan bahasa arab adalah bahasa asing dan bahasa yang memiliki terjemahan kata yang banyak dan memelukan hafalan-hafalan ada beberapa fungsi di 
dalam pembelajaran bahasa Arab, fungsi pembelajaran bahasa Arab yang dimaksud adalah fungsi individu dan fungsi sosial. ${ }^{1}$ Secara umum fungsi bahasa untuk meningkatkan kemampuan peserta didik didalam berkomunikasi secara lisan maupun tulisan dan sebagai alat atau media komunikasi antar manusia sehari-hari, baik di rumah, disekolah dan di tempat-tempat umum.

Dalam proses pelaksanaan pendidikan di sekolah, salah satu faktor yang menentukan keberhasilan dalam proses belajar mengajar adalah faktor antara Guru dengan siswa, serta faktor ketepatan menentukan metode mengajar. Metode mengajar merupakan salah satu bagian dalam kegiatan mengajar, guna mencapi tujuan pengajaran dan tujuan pendidikan. Dalam hal ini, pendidikan telah mengemukakan jenis-jenis metode mengajar yang dapat digunakan untuk menyampaikn materi pelajaran. Metode yang baik dalam pembelajaran adalah metode yang dapat meningkatkan minat belajar siswa. ${ }^{2}$

Sebaiknya Guru yang profesional dan kreatif justru akan memilih metode yang tepat setelah menetapkan topik pembahasan materi dan tujuan pelajaran serta jenis kegiatan belajar siswa yang dibutuhkan. Metode merupakan salah satu upaya untuk mencapai tujuan, dan penggunaan metode driil/latihan pun juga merupakan upaya Guru untuk mencapai tujuan pendidikan yang telah ditetapkan dengan meraih prestasi yang sebaik mungkin, di samping untuk membangkitkan minat belajar siswa.

1 Zulhannan, Tehnik Pembelajaran Bahasa Arab Interaktif, (Jakarta: Rajawali Press, 2014), hal. 4.

2 Pera Purwanti, Pengaruh Penerapan Metode Drill/Latihan Terhadap Minat Belajar Pada Mata Pelajaran Fiqih, (Jurnal Pendidikan Universitas Garut, Volume. 4, Nomor. 1, 2010), hal. 48. 
Hafidh Nur Fauzi, Muhammad Arif Darmawan : Penerapan Metode Drill dalam Pembelajaran Bahasa Arab untuk Meningkatkan Hasil Belajar

Dari permasalahan pembelajaran di atas maka, pembelajaran bahasa Arab dapat dilakukan dengan berbagai pendekatan, salah satunya dengan metode drill. Metode drill merupakan metode atau cara mengajar yang digunakan para guru untuk mempermudah dalam menghafal dan memperbanyak pratek memberikan latihan dari suatu kegiatan belajar yang bertujuan agar siswa aktif dalam mengerjakan soalsoal latihan dengan kemapuan yang dimiliki, untuk membantu siswa mencapai prestasi yang maksimal dalam belajar.

Secara teoritik metode driil/latihan yang digunakan oleh Guru dalam penyampaian materi pelajaran akan member pengaruh kepada siswa. Jika penggunaan metode driil/latihan dalam proses belajar mengajar baik, maka akan mempengaruhi terhadap minat belajar siswa sehingga minat belajarnya baik pula. Sebaliknya apabila penggunaan metode tersebut jelek, maka tidak akan muncul minat belajar dan kecil kemungkinan untuk memperoleh prestasi yang baik.

Dalam proses pembelajaran cara yang dianggap cocok untuk menanamkan konsep baru (yang ada kaitanya dengan konsep lama) adalah dengan cara stimulasi respon yang dilakukan melalui drill (latihan) yang tepat dan berulang-ulang". Oleh karena itu dengan menggunakan metode drill ini, siswa diharapkan memiliki ketangkasan dan keterampilan yang lebih tinggi dari apa yang dipelajari. ${ }^{3}$ Seperti halnya diketahui bahwa penerapan metode drill dalam pembelajaran bahasa arab sangat efektif untuk meningkatkan prestasi belajar peserta didik. ${ }^{4}$

3 Ayok Ariyanto, Pengunaan Metode Drill dalam pembelajaran, (Jurnal Muaddib, Volume. 06, No 1. 2016), hal. 20.

4 Arif Safrianto dkk, Penerapan Metode Drill Dalam Pembelajaran Bahasa Arab Untuk Meningkatkan Prestasi Belajar Siswa Kelas IV di Madrasah Ibtidaiyah, (Jurnal Tarbawi, Volume. 3 No. 1. 2019), hal, 33. 
Hafidh Nur Fauzi, Muhammad Arif Darmawan : Penerapan Metode Drill dalam Pembelajaran Bahasa Arab untuk Meningkatkan Hasil Belajar

Sementara itu keunggulan dari metode drill dalam pross pembelajaran adalah juga dapat meningkatkan keterampilan peserta didik dalam menyimak sebuah materi. ${ }^{5}$

Berdasarkan observasi dan wawancara guru bahasa arab dan siswa yang di lakukan di SD Muhammadiyah Pendowoharjo untuk materi bahasa Arab kelas $\mathrm{V}$ masih belum mencapai nilai KKM yaitu $70 \%$ dari jumlah siswa, ini sebabkan karena guru masih mengunakan metode konvensional dan kurang berfariatif kemudian hanya memberikan latihan di LKS (Lembar Kerja Siswa) di setiap pertemuan, ini yang menyebabkan peserta didik merasa jenuh dan kurang bersemangat dalam pembelajaran. Pernyataan ini didukung oleh fenomena yang ada di kelas V SD Muhammadiyah Pendowoharjo dengan jumlah peserta didik 14 orang yang terdiri dari 8 laki-laki dan 6 perempuan, dari jumlah tersebut hanya 4 peserta didik atau $45 \%$ yang sudah memenuhi standar nilai KKM sementara 10 peserta didik lainnya atau $55 \%$ belum memenuhi standart KKM. Dari bebrapa fenomena di atas maka di perlukan solusi atau strategi pembelajaran yang sesuai dengan pembelajaran bahsa Arab sehingga mendorong dan memotivasi peserta didik untuk meningkatkan prestasi dan keinginnan untuk terus memperdalam bahasa Arab.

\section{B. METODE PENELITIAN}

Penelitian ini memakai jenis Penelitian Tindakan Kelas (PTK). PTK diartikan sebagai penyelidikan ilmiah dalam bentuk refleksi diri yang melibatkan guru dalam situasi pendidikan dengan tujuan memperbaiki pemahaman dan keadilan tentang situasi atau praktik. Pendekatan Praktik diartikan sebagai hasil

5 Wahyu, Penerapan Metode Drill Untuk Meningkatkan Keterampilan Menyimak Siswa, (FKIP UNTAN, 2019), hal. 1. 
Hafidh Nur Fauzi, Muhammad Arif Darmawan : Penerapan Metode Drill dalam Pembelajaran Bahasa Arab untuk Meningkatkan Hasil Belajar

pengamatan suatu penelitian di tunjukan dengan fakta lapangan maupun berupa angka. 6 Prosedur Penelitian Tindakan Kelas ini dilakukan dengan menggunakan siklus mengacu pada empat komponen meliputi (planning), tindakan (acting), pengamatan (observing), dan refleksi (reflecting) ${ }^{7}$

Penelitian Tindakan Kelas (PTK) digunakan dengan tujuan dalam suatu kegiatan penelitian yang berkonteks kelas yang dilaksanakan untuk memecahkan masalah-masalah pembelajaran yang dihadapi oleh guru, memperbaiki mutu dan hasil pembelajaran dan mencobakan hal-hal baru dalam pembelajaran demi peningkatan mutu dan hasil pembelajaran. ${ }^{8}$

Tiap siklus dilaksanakan sesuai dengan indikator yang hendak dicapai yaitu pemahaman konsep belajar siswa meningkat setelah dilakukannya sebuah tindakan siklus ini sesuai dengan dikembang oleh Kemmis \& Mc. Taggart yang menggunakan 4 komponen penelitian dalam suatu sistem alur pelaksanaan tindakan kelas yang saling terkait antara langkah yang satu dengan langkah berikutnya. Tahap-tahap dalam penelitian tindakan ini masing-masing akan diuraikan sebagai berikut:

6 Suharsimi Arikunto, Prosedur penelitian Suatu Pendekaan Praktek, (Jakarta: Rineka Cipta, 1993), hal. 43.

7 Zainal Aqib, Penelitian Tindakan Kelas, (Bandung: Yrama Widya, 2009), hal. 22 .

8 Ani Widayati, Penelitian Tindakan Kelas, (Jurnal Pendidikan Akuntasi Indonesia, Volume. 6, No. 1, 2008), hal. 87. 


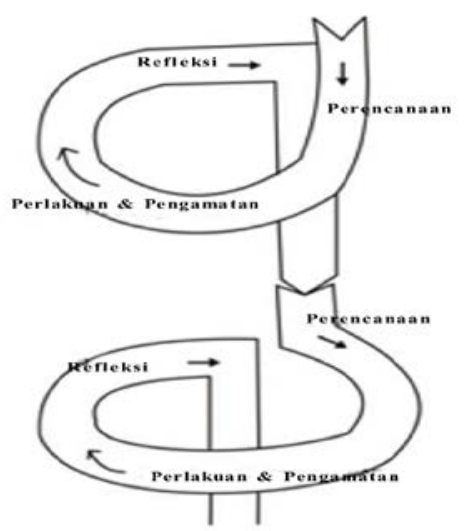

Gambar 1.0 Alur PTK Kemmis and Taggart. 9

Adapaun data yang akan peneliti kumpulan meliputi tes (pre test, post test), hasil wawancara, hasil observasi, hasil dokumentasi. Analisis data dalam penelitian ini menggunakan analisis data kualitatif yaitu analisis data yang diperoleh berbentuk kalimat-kalimat dan aktifitas-aktifitas siswa dan guru. Model analisis yang digunakan oleh Miles dan Herman) yaitu model mengalir (flow model), yaitu meliputi tiga hal yaitu mereduksi data, menyajikan data, menarik kesimpulan. ${ }^{10}$

\section{PEMBAHASAN}

\section{Pengertian Metode Drill (Kelebihan dan kekurangan)}

Metode adalah cara yang digunakan untuk mengimplementasikan rencana yang sudah disusun dalam kegiatan nyata agar tujuan yang telah disusun tercapai secara optimal. Menurut J. R David dalam teaching Strategies For College Class Roomseperti yang dikutip oleh

9 Rochiati Wiriaatmadja, Metode Penelitian Tindakan Kelas (Bandung: PT Remaja Rosdakarya, 2010), hal. 66.

10 Matthew B. Milles, A. Michael Huberman, Analisis Data Kualitatif, (Jakarta: Universitas Indonesia Press, 1992), hal. 56. 
Hafidh Nur Fauzi, Muhammad Arif Darmawan : Penerapan Metode Drill dalam Pembelajaran Bahasa Arab untuk Meningkatkan Hasil Belajar

Majid, menyebutkan bahwa method is a way in achieving something (cara untuk mencapai sesuatu). Artinya, metode digunakan untuk merealisasikan strategi yang telah ditetapkan. ${ }^{11}$

Secara harfiah metode berarti cara. Di dalam kamus umum Bahasa Indonesia, metode diartikan sebagai cara yang telah teratur dan terpikir baik- baik untuk mencapai sesuatu maksud. Metode dapat pula diartikan sebagai cara melakukan sesuatu kegiatan atau cara melakukan pekerjaan dengan menggunakan fakta-fakta dan konsepkonsep secara sistematis. ${ }^{12}$

Metode latihan (Drill) yang disebut juga dengan training, merupakan suatu cara mengajar yang baik untuk menanamkan kebiasaan- kebiasaan tertentu. Juga sebagai sarana untuk memelihara kebiasaan- kebiasaan yang baik. Selain itu metode ini juga baik untuk memperoleh suatu ketangkasan, ketepatan, kesempatan dan keterampilan. ${ }^{13}$

Metode drill/latihan yaitu suatu cara mengajar dimana siswa melaksanakan kegiatan-kegiatan latihan, agar siswa memiliki ketangkasan atau ketrampilan yang lebih tinggi dari apa yang dipelajari. Nana Sudjana mengemukakan bahwa metode drill/latihan yaitu satu kegiatan melakukan hal yang sama, berulang-ulang secara sungguh-sungguh dengan tujuan untuk memperkuat suatu asosiasi atau menyempurnakan suatu ketrampilan agar menjadi bersifat permanen. Ciri yang khas dari metode ini

11 Abdul Majid, Strategi Pembelajaran, (Bandung: PT Remaja Rosdakaraya, 2013), hal. 193.

12 Muhibbin Syah, Psikologi Pendidikan (Suatu Pendekata Baru). (Bandung: Remaja Rosdakarya, 2001), hal. 87.

13 Syaiful Bahri Djamarah dan Aswan Zaim, Strategi Belajar Mengajar, (Jakarta, PT. Rineka Cipta; 2010), hal. 95. 
adalah kegiatan berupa pengulangan yang berkali-kali dari suatu hal yang sama. ${ }^{14}$

Keuntungan Atau Kebaikan Metode Drill adalah pertama, Bahan pelajaran yang diberikan dalam suasana yang sungguh-sungguh akan lebih kokoh tertanam dalam daya ingatan murid, karena seluruh pikiran, perasaan, kemauan dikonsentrasikan pada pelajaran yang dilatihkan. Kedua, anak didik akan dapat mempergunakan daya fikirannya dengan bertambah baik, karena dengan pengajaran yang baik maka anak didik akan menjadi lebih teratur, teliti dan mendorong daya ingatnya. Kketiga, adanya pengawasan, bimbingan dan koreksi yang segera serta langsung dari guru, memungkinkan murid untuk melakukan perbaikan kesalahan saat itu juga.

Sedangkan Kelemahan metode drill/latihan adalah pertama latihan yang dilakukan di bawah pengawasan yang ketat dan suasana serius mudah sekali menimbulkan kebosanan. Kedua, tekanan yang lebih berat, yang diberikan setelah murid merasa bosan atau jengkel tidak akan menambah gairah belajar dan menimbulkan keadaan psikis berupa mogok belajar/latihan. Ketiga, latihan yang terlampau berat dapat menimbulkan perasaan benci dalam diri murid, baik terhadap pelajaran maupun terhadap guru. Keempat, latihan yang selalu diberikan di bawah bimbingan guru, perintah guru dapat melemahkan inisiatif maupun kreatifitas siswa. Kelima, karena tujuan latihan adalah untuk mengkokohkan asosiasi tertentu, maka murid akan

14 Nana Sudjana, Dasar-Dasar Proses Pembelajaran (Bandung : Sinar Baru Algesindo, 1998), hal. 20. 
Hafidh Nur Fauzi, Muhammad Arif Darmawan : Penerapan Metode Drill dalam Pembelajaran Bahasa Arab untuk Meningkatkan Hasil Belajar

merasa asing terhadap semua struktur-struktur baru dan menimbulkan perasan tidak berdaya.

\section{Langkah-langkah penerapan metode Drill.}

Langkah-langkah dalam melaksanakan latihan baik untuk belajar verbal ataupun belajar keterampilan adalah sebagai berikut:

a. Guru memberi penjelasan singkat tentang konsep, prinsip, atau aturan yang menjadi dasar dalam melaksanakan pekerjaan yang akan dilatihkan.

b. Guru mempertunjukkan bagaimana melakukan pekerjaan itu dengan baik dan benar sesuai dengan konsep dan aturan tertentu. Pada bentuk pelajar verbal yang dipertun jukkan adalah pengucapan atau penulisan kata atau kalimat.

c. Jika belajar dilakukan secara kelompok atau klasikal, guru dapat memerintah salah seorang siswa untuk menirukan apa yang telah dilakukan guru, sementara siswa lain memperhatikan.

d. Latihan perseorangan dapat dilakukan melalui bimbingan dari guru sehingga dicapai hasil belajar sesuai dengan tujuan. 15

\section{Penerapan Metode Drill dalam pembelajaran bahasa Arab} di SD Muhammadiyah Pendowoharjo

Metode Drill dalam pembelajaran bahasa Arab merupakan hal yang baru bagi peneliti khususnya bagi siswa kelas V SD Muhammadiyah Pendowoharjo karena baru pertama kali peneliti menerapkannya. Pada proses pelaksanaan metode drill pada pokok bahasan Adawatul

15 Sumiati dan Asra, Metode Pembelajaran, (Bandung: CV. Wacana Prima, 2011), hal. 105. 
madrosiah, terdapat banyak kekurangan dalam pelaksanaan pembelajarannya, baik dari aktivitas guru maupun aktivitas siswa/peserta didik.

Pada awal pelaksanaan tepatnya pada siklus 1 sebagian besar dari peserta didik kesulitan dalam mengikuti pembelajaran mengunakan metode drill dan kurang semangat dalam mengikuti pelajaran akhirnya tanpa sepengetahuan peneliti saat diadakan post test pada siklus 1 banyak dari mereka yang mencontek terlihat banyaknya jawaban yang sama antara peserta didik satu dan lainya. Pada proses pembelajaran di kelas tampak ramai dan kurang kondusif dikarenakan sebagian siswa laki-laki bercanda dengan teman sebangku dan bermain sendiri, sehingga proses pembelajaran kurang maksimal.

Dengan kondisi kelas yang seperti itu peneliti merasa kesulitan dalam menyampaikan materi pembelajaran sehingga, perhatian guru kepada peserta didik masih kurang maksimal dan kurang memanfaatkan waktu pembelajaran secara maksimal sesuai waktu yang ditetapkan selama kurang lebih 2x35 menit. Dikarenakan adanya kekurangan dan tingkat keberhasilan metode drill pada siklus 1 kurang sesuai dengan harapan peneliti dan harus adanya tindakkan perbaikan pada siklus 2 dan hasilnya pada siklus 2 kekurangan-kekurangan dapat dipertbaiki dan meningkat secara seknifika.

Kegiatan pengamatan aktivitas guru dilaksanakan besamaan dengan proses pembelajaran dikelas, hasil data pengamatan aktiviasa guru dan siswa dapat digunakan untuk mengetahui seberapa besar pencapaian proses belajar mengajar guru dan murid. 
Hafidh Nur Fauzi, Muhammad Arif Darmawan : Penerapan Metode Drill dalam Pembelajaran Bahasa Arab untuk Meningkatkan Hasil Belajar

Tabel 1. Hasil Pre-test dan Post-test

\begin{tabular}{|c|l|c|c|c|}
\hline No & \multicolumn{1}{|c|}{ Penilaian } & $\begin{array}{c}\text { Pre- } \\
\text { test }\end{array}$ & $\begin{array}{c}\text { Post test } \\
1\end{array}$ & $\begin{array}{c}\text { Post test } \\
2\end{array}$ \\
\hline 1 & $\begin{array}{l}\text { Jumlah kehadiran } \\
\text { siswa }\end{array}$ & 12 & 12 & 12 \\
\hline 2 & Akumulasi nilai siswa & 715 & 800 & 900 \\
\hline 3 & Rerata kelas & 60 & 66 & 75 \\
\hline 4 & Persentase ketuntasan & $25 \%$ & $50 \%$ & $75 \%$ \\
\hline 5 & Kategori & kurang & cukup & baik \\
\hline
\end{tabular}

Tabel 2. Hasil Pengamatan Aktifitas Guru

\begin{tabular}{|c|l|c|c|}
\hline \multirow{2}{*}{ NO } & \multicolumn{2}{|c|}{ Penilaian } & \multicolumn{2}{c|}{ Siklus } \\
\cline { 3 - 4 } & & Siklus 1 & Siklus 2 \\
\hline 1 & Skor Maksimal & 44 & 44 \\
\hline 2 & Skor Perolehan & 22 & 32 \\
\hline 3 & Persentase & $50 \%$ & $72 \%$ \\
\hline 4 & Kategori & kurang & baik \\
\hline
\end{tabular}

Tabel 3. Hasil Pengamatan Aktifitas Siswa

\begin{tabular}{|c|l|c|c|}
\hline NO & \multicolumn{2}{|c|}{ Penilaian } & \multicolumn{2}{c|}{ Siklus } \\
\cline { 3 - 4 } & & Siklus 1 & Siklus 2 \\
\hline 1 & Skor Maksimal & 40 & 40 \\
\hline 2 & Skor Perolehan & 19 & 26 \\
\hline 3 & Persentase & $47,5 \%$ & $70 \%$ \\
\hline 4 & Kategori & kurang & baik \\
\hline
\end{tabular}

Berdasarkan data perolehan hasil pengamatan aktivitas guru dan siswa adanya peningkatan presentase hal ini menujukkan bahwa aktivitas guru dan siswa meningkat dari siklus 2 ke siklus 2 . Hasil aktivitas guru pada siklus 1 $50 \%$ menjadi $72 \%$ pada siklus 2 dengan kategori ketuntasan baik sedangkan hasil aktivitas siswa pada siklus $147,5 \%$ mejadi $70 \%$ pada siklus 2 dengan perolehan kategori baik, berdasarkan data perbandingan pengamatan hasil aktiviatas guru dan siswa pada siklus 1 dan 2 pada proses pembelajaran mengunakan merode drill di mata pelajaran 
bahsa arab pada pokok bahasan adawatulmadrosiah mengalami peningkatan mencapai lebih dari $70 \%$.

Kegiatan tes individu meliput tes pra tindakan atau disebut pre test untuk mengukur tingkat pemahaman peserta didik terkait materi-materi sebelumnya selanjutnya adalah tahap tes setelah di terapkannya metode drill dalam pembelajran bahasa Arab pada pokok bahasan adawatulmadrosiah yaitu post tes pada setiap siklus. Adapun hasil tes individu pada siklus 1 dan 2 dijelaskan secara deskriptif.

Berdasarkan data rekapitulasi hasil tes siswa dari siklus 1 dan siklus 2 presentasi KKM siswa meningkat dari mulai pre test, post test 1 dan post test 2 terlihat pada tahapan tes terakhir pada siklus 2 mencapai $75 \%$ yang sebelumnya hanya $50 \%$ dari $75 \%$ hanya 3 orang siswa yang belum mencapai nilai KKM yaitu 71 dari 12 siswa. Dengan adanya peningkatan hasil belajar para peserta didik bahwa penerapan metode drill di mata pelajaran bahasa Arab pada pokok bahasan adawatulmadrosiah terbilang berhasil dan telah memenuhi KKM yang diharapkan peneliti.

\section{KESIMPULAN}

Berdasarkan data dan hasil dari proses penelitian yang dilakukan. Menujukkan bahwa penerapan metode drill pada mata pelajaran bahasa Arab dengan materi adawatul madrosiah di kelas V SD Muhammadiyah Pendowoharjo sudah lebih baik dari sebelumnya dibuktikan dengan hasil pengamatan pada siklus 1 dan siklus 2 terlihat adanya peningkatan efektivitas siswa dalam pembelajaran dari $47.5 \%$ meningkat menjadi $70 \%$ dengan kategori baik dan hasil tes seluruh siswa kelas $\mathrm{V}$ dari 
Hafidh Nur Fauzi, Muhammad Arif Darmawan : Penerapan Metode Drill dalam Pembelajaran Bahasa Arab untuk Meningkatkan Hasil Belajar

nilai rata-rata obesrvasi awwal pada pre test sebesar 60 menglami peningkatan pada siklus terakhir menjadi 75 ini membuktikan adanya peningkatan dari hasil prestasi siswa. Pada prsentase nilai Kriteria Ketuntasan Minimal (KKM) juga mengalami peningkatan dengan perolehan nilai $>71$ pada post test 2 dan dari hasil siklus 1 ke siklus 2 sebesar 50\% naik menjadi $75 \%$.

Adapun faktor pendukung dalam penerapan metode drill dalam pembelajaran bahasa Arab secara garis besar sebagian dari mereka termotivasi untuk bisa berbicara bahasa Arab sehingga keingginan dan semangat mereka dalam pembelajaran lebih dari pada yang lain sebaliknya faktor penghambat dari pembelajaran bahasa Arab ada beberapa siswa yang belum mampu membaca kalimat-kalimat ber-bahasa Arab sehingga mereka terhambat dalam memahami penjelasan dalam proses pembelajaran bahasa Arab menggunakan metode drill. 


\section{DAFTAR PUSTAKA}

Abdul Majid, Strategi Pembelajaran, (Bandung: PT Remaja Rosdakaraya, 2013),

Ani Widayati, Penelitian Tindakan Kelas, (Jurnal Pendidikan Akuntasi Indonesia, Volume. 6, No. 1, 2008).

Arif Safrianto dkk, Penerapan Metode Drill Dalam Pembelajaran Bahasa Arab Untuk Meningkatkan Prestasi Belajar Siswa Kelas IV di Madrasah Ibtidaiyah, (Jurnal Tarbawi, Volume. 3 No. 1. 2019).

Ayok Ariyanto, Pengunaan Metode Drill dalam pembelajaran, (Jurnal Muaddib, Volume. 06, No 1. 2016).

Matthew B. Milles, A. Michael Huberman, Analisis Data Kualitatif, (Jakarta: Universitas Indonesia Press, 1992).

Muhibbin Syah, Psikologi Pendidikan (Suatu Pendekata Baru). (Bandung: Remaja Rosdakarya, 2001).

Nana Sudjana, Dasar-Dasar Proses Pembelajaran (Bandung: Sinar Baru Algesindo, 1998).

Pera Purwanti, Pengaruh Penerapan Metode Drill/Latihan Terhadap Minat Belajar Pada Mata Pelajaran Fiqih, (Jurnal Pendidikan Universitas Garut, Volume. 4, Nomor. 1, 2010).

Rochiati Wiriaatmadja, Metode Penelitian Tindakan Kelas (Bandung: PT Remaja Rosdakarya, 2010).

Suharsimi Arikunto, Prosedur penelitian Suatu Pendekaan Praktek, (Jakarta: Rineka Cipta, 1993).

Sumiati dan Asra, Metode Pembelajaran, (Bandung: CV. Wacana Prima, 2011

Syaiful Bahri Djamarah dan Aswan Zaim, Strategi Belajar Mengajar, (Jakarta, PT. Rineka Cipta; 2010).

Wahyu, Penerapan Metode Drill Untuk Meningkatkan Keterampilan Menyimak Siswa, (FKIP UNTAN, 2019). 
Hafidh Nur Fauzi, Muhammad Arif Darmawan : Penerapan Metode Drill dalam Pembelajaran Bahasa Arab untuk Meningkatkan Hasil Belajar

Zainal Aqib, Penelitian Tindakan Kelas, (Bandung: Yrama Widya, 2009).

Zulhannan, Tehnik Pembelajaran Bahasa Arab Interaktif, (Jakarta: Rajawali Press, 2014). 